\title{
La medida del potencial zeta. Relaciones con la finura en arenisca
}

\section{Measuring the zeta potential. The relationships with sandstone fineness}

\author{
M. ${ }^{a}$ P. de LUXÁN y M. ${ }^{a}$ I. SÁNCHEZ de ROJAS, Dras. en Ciencias Químicas. \\ M. FRÍAS, Lcdo. en Ciencias Quimicas \\ ICCET/CSIC \\ M. ${ }^{a}$ T. PATINO, Dra. en Ciencias Quimicas \\ Universidad Autónoma de Madrid/CSIC

\section{RESUMEN}

La aplicación de la técnica del potencial zeta en el campo de los materiales de construcción y del cemento portland es muy reciente. Las primeras investigaciones se refieren al estudio de suspensiones de cemento o de alguno de sus compuestos que lo forman como alita, aluminato tricálcico, en presencia de aditivos y, más concretamente, de superfluidificantes. Con la incorporación de adiciones activas al cemento (cenizas volantes....) se amplian los estudios de este tipo de cementos. En este trabajo se considera la aplicación a los materiales siliceos (arenisca) como base para la investigación del comportamiento de los morteros de arenisca conteniendo productos de reparación.

\begin{abstract}
The application of the zeta potential technique in the area of construction materials and Portland cement is quite recent. The initial research work involved the study of cement suspensions or suspensions of one of the components of cement, such as alite, tricalcium aluminate, in the presence of additives and, more specifically, superplasticizers. The studies of this sort were extended with the mixing of active additions into cement (fly ashes, etc.). The present study discusses the application of siliceous materials (sandstone) as a basis of the research into the behaviour of sandstone mortars containing repair products.
\end{abstract}

\section{INTRODUCCION}

Con el fin de ampliar y mejorar las posibilidades de empleo del cemento y de su colocación se ha buscado la incorporación de aditivos que modifiquen sus propiedades reológicas. Con ello se abre un campo de investigación, en el que la estabilidad del sistema coloidal está en función del potencial zeta, por lo que la medida del mismo contribuye al conocimiento del mecanismo de las reacciones de hidratación del cemento.

La aparición de trabajos de investigación sobre la determinación del potencial zeta en las publicaciones especializadas en el campo de los conglomerantes hidraúlicos de estos últimos años ha ido en aumento.

Tras una breve exposición de la medida del potencial zeta y de la técnica en la que está

\section{INTRODUCTION}

The mix of cement with additives capable of changing its rheologic properties has been studied with the purpose of increasing and improving the possibilities of using and placing cement. This opens a new research field where the stability of the colloidal system is a function of the zeta potential and therefore, measuring this potential contributes to the understanding of the cement hydration reactive mechanism.

The publication of research work on the determination of the zeta potential in journals specialising in the area of hydraulic binders has increased in recent years.

After a brief discussion of the measurement of the zeta potential and of the technique on 
basada, se expone en este trabajo un resumen de las líneas de investigación desarrolladas dentro del área del cemento $\mathrm{y}$, finalmente, se presentan los resultados obtenidos con materiales silíceos (arenisca).

\section{POTENCIAL ZETA}

La medida del potencial zeta expresa la movilidad electroforética de las partículas de un material, cuando éste se encuentra disperso en un líquido. El método de electroforesis se basa en la aplicación de un campo eléctrico que produce la migración de las partículas coloidales debida al potencial y a la carga.

En el cálculo del potencial zeta intervendrán tanto las características del material como las del líquido en el que se encuentra disperso, estas características son:

- Densidad del material, dm, (g/cc).

- Temperatura del ensayo, $\mathrm{T},\left({ }^{\circ} \mathrm{C}\right)$.

- Densidad del líquido, dl, (g/cc).

- Viscosidad del líquido, $\eta \mathrm{l}$, (poise).

- Constante dieléctrica del líquido, DI.

- Porcentaje (en peso y en tanto por uno) del material, $\mathrm{fm}$.

- Tiempo de aplicación del gradiente de potencial, $t,(s)$.

- Intensidad de la corriente, I, (amperios).

- Signo del electrodo. [Cuando el electrodo de la célula es positivo y el material emigra dentro de la misma (partículas negativas), la movilidad electroforética es, por convenio, negativa].

- Peso de la célula antes y después del ensayo. (Peso de la muestra que ha emigrado al interior de la célula), $\Delta \mathrm{w},(\mathrm{g})$.

- Constante de conductividad de la célula, $\mathrm{c},(1 / \mathrm{cm})$.

- Resistencia de la muestra, R, (ohms).

Para la determinación del potencial zeta es necesario definir:

$$
\varnothing=\text { fracción de sólido }=\frac{\mathrm{fm} / \mathrm{dm}}{(\mathrm{fm} / \mathrm{dm})+(\mathrm{fl} / \mathrm{dl})}
$$

which such measument is based, the present paper presents a summing up of the research lines developed within the cement field and, finally, the results obtained with siliceous materials (sandstone) are shown.

\section{ZETA POTENTIAL}

The measurement of the zeta potential expresses the electrophoretic mobility of the particles of a material when this material is dispersed in a liquid. The electrophoresis method is based on the application of an electric field causing colloidal particles to migrate as a function of the electric potential and charge.

Both the material and the dispersion liquid characteristics are taken into account in the zeta potential calculation, including:

- Material density, dm, (g/cc).

- Test temperature, $T,\left({ }^{\circ} \mathrm{C}\right)$.

- Liquid density, dl, (g/cc).

- Liquid viscosity, $\eta l$, (poise).

- Dielectric constant of liquid, DI.

- Percentage (by weight and fractions of one) of the material, $\mathrm{fm}$.

- Time of potential gradient application, $t$, (s).

- Current intensity, I, (amperes).

- Electrode sign. [When the cell electrode is positive and material migrates into the cell (negative particles), electrophoretic mobility is, by convention, negative].

- Cell weight before and after testing. (Weight of an in-cell migrating sample), $\triangle w,(g)$.

- Conductivity cell constant, c, $(1 / \mathrm{cm})$.

- Slurry resistence, $R$, (ohms).

The following must be defined to determine the zeta potential:

$$
\varnothing=\text { fraction of solid }=\frac{\mathrm{fm} / \mathrm{dm}}{(\mathrm{fm} / \mathrm{dm})+(\mathrm{fl} / \mathrm{dl})}
$$




$$
\begin{gathered}
\mathrm{v}_{\varepsilon}=\text { movilidad electroforética }=\frac{\Delta \mathrm{w} \cdot \mathrm{c}}{\mathrm{R} \cdot \mathrm{t} \cdot \mathrm{l} \cdot \varnothing(1-\varnothing) \cdot(\mathrm{dm}-\mathrm{dl})} ; \text { expresada en }(\mathrm{cm} / \mathrm{s} \cdot \mathrm{volt} / \mathrm{cm}) \\
\mathrm{v}_{\varepsilon}=\text { electrophoretic movility }=\frac{\Delta \mathrm{w} \cdot \mathrm{c}}{\mathrm{R} \cdot \mathrm{t} \cdot \mathrm{l} \cdot \varnothing(1-\varnothing) \cdot(\mathrm{dm}-\mathrm{dl})} ; \text { expressed in }(\mathrm{cm} / \mathrm{s} \cdot \mathrm{volt} / \mathrm{cm})
\end{gathered}
$$

El potencial zeta vendrá dado por:

$$
\mathrm{Z}=\frac{\left(36 \cdot 10^{4}\right) \cdot \pi \cdot \mathrm{V}_{\varepsilon} \cdot \eta 1}{\mathrm{DI}} ; \text { (volts) }
$$

Esta medida está directamente relacionada con otras cualidades físicas características del propio material, como son:

- la estabilidad de los coloides;

- los fenómenos de suspensión;

- la flotabilidad;

- la viscosidad;

- la facilidad de filtración de suspensiones; etc.

Por este motivo, la medida del potencial zeta se utiliza, en distintos ámbitos de la investigación, como medio para estudiar la evolución de las características de un material frente a diferentes medios.

\section{INVESTIGACIONES DE LAS \\ CARACTERISTICAS Y PROPIEDADES DE LOS CONGLOMERANTES HIDRÁULICOS $Y$ SU RELACIÓN CON LA MEDIDA DEL POTENCIAL ZETA}

Las investigaciones acerca de la medida del potencial zeta en relación con las caracteristicas y propiedades de los conglomerantes hidraúlicos comprenden estudios diversos sobre los distintos compuestos del clínker, el cemento portland, cementos con puzolanas y cenizas volantes, así como la influencia de los aditivos, en especial de los superfluidificantes, en la fase inicial de los fenómenos de hidratación del cemento.

Massazza y Testolin (1980) (1) investigaron los cambios que se producen en el potencial zeta con suspensiones de silicato tricálcico, al añadir aditivos de tipo aniónico y de tipo no aniónico.

Al aumentar el contenido de aditivos no iónicos el potencial zeta apenas sufre cambio, sin embargo, con aditivos de tipo iónico el
The zeta potential will be given by:

$$
\mathrm{Z}=\frac{\left(36 \cdot 10^{4}\right) \cdot \pi \cdot \mathrm{V}_{\varepsilon} \cdot \eta 1}{\mathrm{DI}} ;(\text { volts })
$$

This measurement is directly related to other physical properties inherent to the material, namely:

- the stability of colloids.

- the suspension phenomena;

- the flotability;

- the viscosity;

- the filterability of suspensions; etc.

For this reason zeta potential measuring is used in different research fields, as a mean to study the development of the characteristics of a material in front of different media.

\section{RESEARCH ON THE CHARACTERISTICS AND PROPERTIES OF HYDRAULIC BINDERS AND THEIR RELATIONSHIP WITH THE MEASUREMENT OF THE ZETA POTENTIAL}

Research on the measurement of the zeta potential in relation with the characteristics and properties of hydraulic binders include different studies on the various clinker, portland cement, cements whith pozzolans and fly ashes components, as well as the influence of additives, particularly superplasticizers, in the initial stages of cement hydration phenomena.

Massazza and Testolin (1980) (1) explored the changes occuring in the zeta potential with tricalcium silicate when anionic and non-anionic type additives were mixed in.

Zeta potential does not experience almost any changes on increasing the contents of non-ionic additives, but with ionic type 
valor del potencial zeta se desplaza hacia valores más positivos al aumentar la proporción de aditivo (la concentración de aditivo varía del 0,1 al $3,0 \%$ ).

Costa y Massazza (1984) (2) estudiaron la adsorción de superfluidificantes por el silicato bicálcico, controlando el potencial zeta en distintos medios: disolución saturada de cal y etanol.

En disolución saturada de cal los valores del potencial zeta decrecen cuando la adsorción se incrementa (de $-25 \mathrm{a}-30 \mathrm{mV}$ ). Cuando el ensayo se realiza en medio alcohólico los valores del potencial zeta se mueven en valores positivos.

Roy y col. (1980) (3) comprobaron como la adición de superfluidificantes en un cemento en suspensión hacia aumentar el potencial zeta hacia valores más negativos; este potencial decrece en el tiempo, estabilizándose a 1.200 minutos. El efecto es similar cuando lo que se estudian son algunos de los componentes del clínker, como la alita y el aluminato tricálcico (4).

El proceso de hidratación de los cementos también puede seguirse mediante la medida del potencial zeta. Su estudio, así como el de la formación de geles que tienen lugar en la hidratación en función de la concentración de aditivos químicos, han sido la base de distintos trabajos de investigación (5), (6). Además, esta medida es una contribución al conocimiento de los efectos que otros productos, como es el sulfato cálcico (7), añadidos al sistema cemento-aditivo, provocan en el mecanismo de hidratación y en la adsorción del aditivo.

Esta adsorción del aditivo por los aluminatos cálcicos formados en la hidratación del cemento se puede igualmente controlar con la medida de potencial zeta (8).

El creciente empleo de los cementos mixtos, mezclas de cemento portland y adiciones activas trajo como consecuencia un incremento en el desarrollo de investigaciones basadas en estudios sobre puzolanas y cenizas volantes.

Nägele (5) estudia la influencia del pH en el potencial zeta para cemento con escorias y cemento con ceniza volante, así como su evolución en el tiempo.

Malek y Roy (1985) (9) por una parte, y Tenoutasse y Marion (1986) (10) por otra, publican los resultados de los ensayos con cenizas volantes bajas en cal en suspensiones acuosas y en presencia de diferentes concentraciones de $\mathrm{Ca}$. additives, the zeta potential value shifts towards more positive values when the proportion of additive is increased (additive concentration varies from $0.1 \%$ to $3.0 \%$ ).

Costa and Massazza (1984) (2) studied the adsorption of superplasticizers by bicalcium silicate, by controlling the zeta potential in different media: lime saturated solution and ethanol.

In a saturated lime solution, the zeta potential values decreased when absorption increased (from -25 to $-30 \mathrm{aV}$ ). When the test was performed in an alcohol medium, the values moved to positive values.

Roy et al. (1980) (3) showed how the addition of superplasticizers to a cement in suspension made zeta potential values increase toward increasingly negative values; this potential decreases with time and is stabilised after 1,200 minutes. The effect is similar when some of the clinker components, such as alite and tricalcium aluminate are tested (4).

The hydration process of cements can also be followed through the measurement of the zeta potential. Such study, as well as the gel formation occurring during hydration as a function of chemical additives concentration, was the basis of several research papers (5), (6). Furthermore, such measurement is a contribution to the understanding of the effects of other products, such as calcium sulphate (7), added to the cement-additive system, provoke on the hydration mechanism and on additive adsorption.

Such adsorption of the additives by calcium aluminates formed in the cement hydration can likewise be controlled with the measuring of the zeta potential (8).

The growing use of mixed cements, portland cement and active additions mixtures, brought about an increase in the development of research work based on pozzolans and fly ashes studies.

Nägele (5) studied the influence of $\mathrm{pH}$ on the zeta potential for slag cements and fly ash cements, as well as their evolution with time.

Malek and Roy (1985) (9) on the one hand, and Tenoutasse and Marion (1986) (10) on the other, published the results of tests with low lime fly ashes in water suspensions and in the presence of different Ca concentrations. 
Respecto al potencial zeta y la trabajabilidad de pastas de cemento portland con microsilice se ha presentado también un trabajo recientemente (11).

Otros estudios sobre las escorias y los efectos de la adición de superfluidificantes se realizaron por Malek, Silsbee y Roy (1986) (12); estos autores miden el valor del potencial zeta para dar una estimación del estado de dispersión de la escoria al añadir el agua de amasado en los cementos.

\section{DETERMINACIONES DEL POTENCIAL ZETA CON LA ARENISCA}

\section{Materiales}

Se ha seleccionado una arenisca como material silíceo cuya caracterızación se encuentra en trabajos anteriores (13). Se ha sometido a un proceso de molienda en el
A work was recently presented on the zeta potential and the workability of portland cement pastes with micro-silica (11).

Malek, Silsbee and Roy (1986) (12) carried out other studies on slags and the effects of superplasticizers; these authors measured the value of zeta potential to give an estimation of the state of dispersion of the slag when mixing water is added to cements.

\section{DETERMINATIONS OF ZETA POTENTIAL WITH SANDSTONE}

\section{Materials}

A sandstone was selected as siliceous material, whose characterization is enclosed in previous papers (13). This sandstone was milled in the laboratory using a cylpebs type

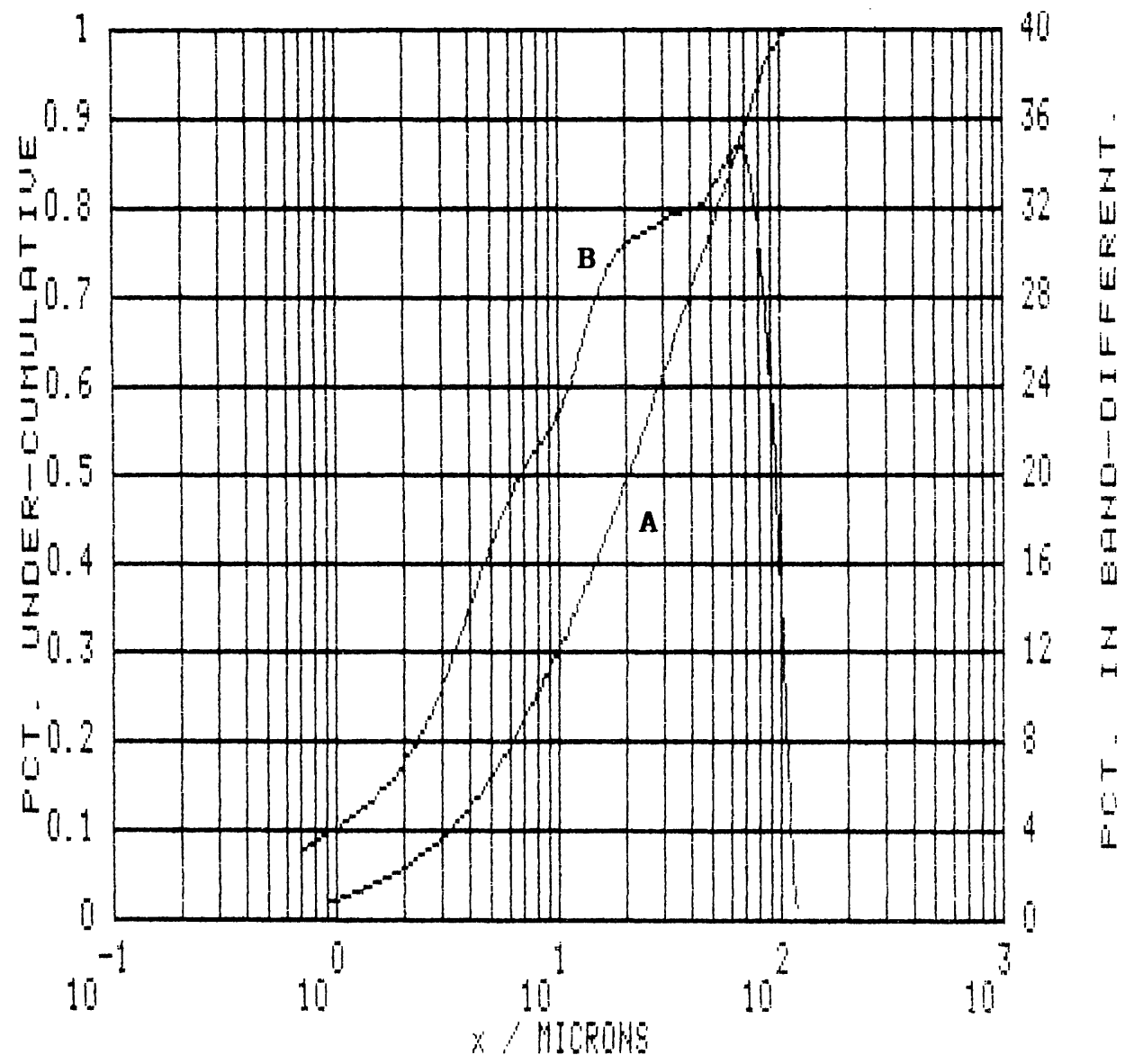

Fig. 1.-Análisis granulométrico. Arenisca $\left(3.500 \mathrm{~cm}^{2} / \mathrm{g} \mathrm{u}\right.$. Blaine).

A: Curva de distribución del tamaño de partícula.

B: Curva de densidad de distribución.

Fig. 1.-Granulometric analysis. Sandstone $\left(3,500 \mathrm{~cm}^{2} / \mathrm{g}\right.$ u. Blaine)

A: Distribution curve of particle size.

B: Curve of distribution density. 
laboratorio mediante un molino de cylpebs, recogiendo muestras a dos finuras diferentes, realizando el control mediante el permeabilímetro Blaine. La superficie específica de cada una de las muestras obtenidas es de 3.500 y $6.000 \mathrm{~cm}^{2} / \mathrm{g} \mathrm{u}$. Blaine.

Posteriormente se separó la fracción de tamaño de partícula inferior a $20 \mu \mathrm{m}$ mediante el elutriador-centrifugador Bahco.

A un mismo valor de la superficie específica le pueden corresponder diferentes curvas de distribución del tamaño de partícula. Con objeto de poder disponer de un control de la finura mayor, se llevó a cabo el análisis granulométrico de cada muestra de arenisca mediante el espectrómetro de difracción por rayos laser, eligiendo como sistema de alimentación la fase líquida y utilizando como líquido dispersante agua destilada, de tal manera que la muestra se analiza en una suspensión acuosa como la empleada en la determinación del potencial zeta. mill and samples of two different grades of fineness were taken; the control was performed using a Blaine permeabilimeter. The specific surface of each sample taken was 3.500 and $6.000 \mathrm{~cm}^{2} / \mathrm{g} \mathrm{u}$. Blaine.

Subsequently, the fraction having a particle size under $20 \mu \mathrm{m}$ was separated by means of a Bahco centrifugue-elutriator.

Different particle size distribution curves may correpond to one single specific surface value. A particle size test was performed of each sandstone sample in order to have a higher fineness control available. A laser beam difraction spectrometer was used for the test, the liquid phase was chosen for feeding and the dispersant liquid was distilled water. In this way, the sample was analysed in a water suspension similar to the suspension used in the determination of the zeta potential.

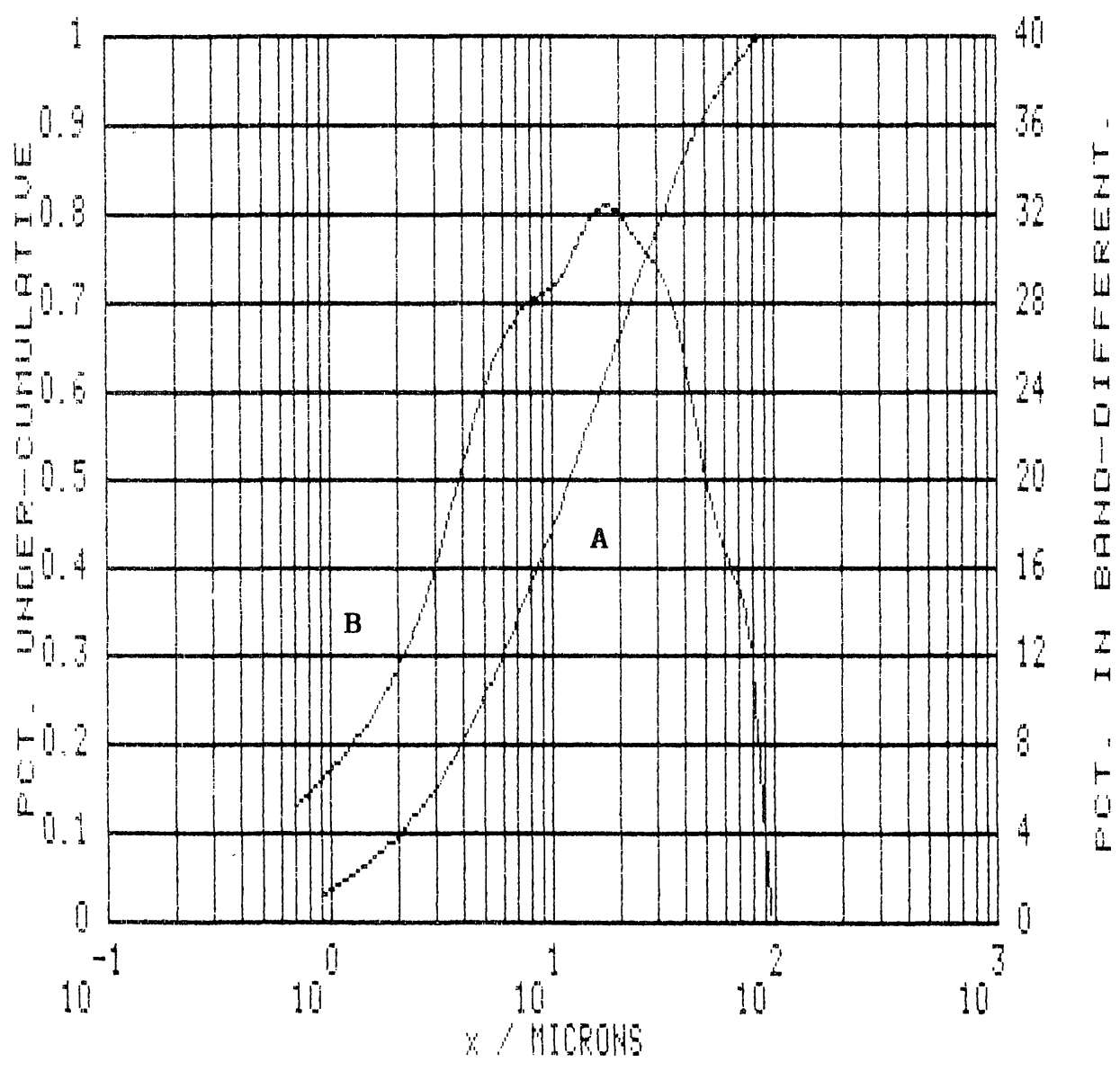

Fig. 2.-Análisis granulométrico. Arenisca $\left(6.000 \mathrm{~cm}^{2} / \mathrm{g} \mathrm{u}\right.$. Blaine $)$.

A: Curva de distribución del tamaño de partícula.

B: Curva de densidad de distribución.

Fig. 2.-Granulometric analysis. Sandstone $\left(6,000 \mathrm{~cm}^{2} / \mathrm{g} \mathrm{u}\right.$. Blaine).

A: Distribution curve of particle size.

$B$ : Curve of distribution density. 
Las curvas de distribución del tamaño de partículas ("A") y las curvas de densidad de distribución logaritmica ("B") se recogen en las figuras 1,2 y 3 , respectivamente para las muestras de: $3.500 \mathrm{~cm}^{2} / \mathrm{g} \mathrm{u}$. B., $6.000 \mathrm{~cm}^{2} / \mathrm{g}$ u. B. y la fracción inferior a $20 \mu \mathrm{m}$ correspondiente a $6.000 \mathrm{~cm}^{2} / \mathrm{g} \mathrm{u}$. B.

Para la finura de $3.500 \mathrm{~cm}^{2} / \mathrm{g}$ el máximo de la curva de densidad de distribución se encuentra para partículas con un diámetro medio de $65 \mu \mathrm{m}$; mientras que para la muestra con finura de $6.000 \mathrm{~cm}^{2} / \mathrm{g}$ aparece a $18 \mu \mathrm{m}$.

Este máximo se encuentra en $15 \mu \mathrm{m}$ para el residuo inferior a $20 \mu \mathrm{m}$; en este caso se observa además como han desaparecido los máximos superiores a este tamaño de $15 \mu \mathrm{m}$ y la anchura de la curva es menor que en los dos casos anteriores; esto significa que los tamaños de las partículas son más similares.
Particle size distribution curves ("A") and logarithmic distribution density curves (" $B$ ") are shown in figures 1, 2 and 3, for the following samples, respectively: $3,500 \mathrm{~cm}^{2} / g$ u. B., $6,000 \mathrm{~cm}^{2} / \mathrm{g} \mathrm{u}$. B. and fraction lower than $20 \mu \mathrm{m}$ corresponding to $6,000 \mathrm{~cm}^{2} / \mathrm{g} \mathrm{u}$. B.

For the $3,500 \mathrm{~cm}^{2} / \mathrm{g}$ fineness, the maximum value of the density distribution curve is foun for particles with an average diameter of $65 \mu \mathrm{m}$, while for the sample with $6,000 \mathrm{~cm}^{2} / \mathrm{g}$ fineness, the maximum value appears at $18 \mu \mathrm{m}$

This maximum is found at $15 \mu \mathrm{m}$ for the residue under $20 \mu \mathrm{m}$; it is further observed in this case that the maximum values higher than the $15 \mu \mathrm{m}$ size have disappeared and the breadth of the curve is smaller than in the two previous cases. This means particle sizes are less dissimilar.

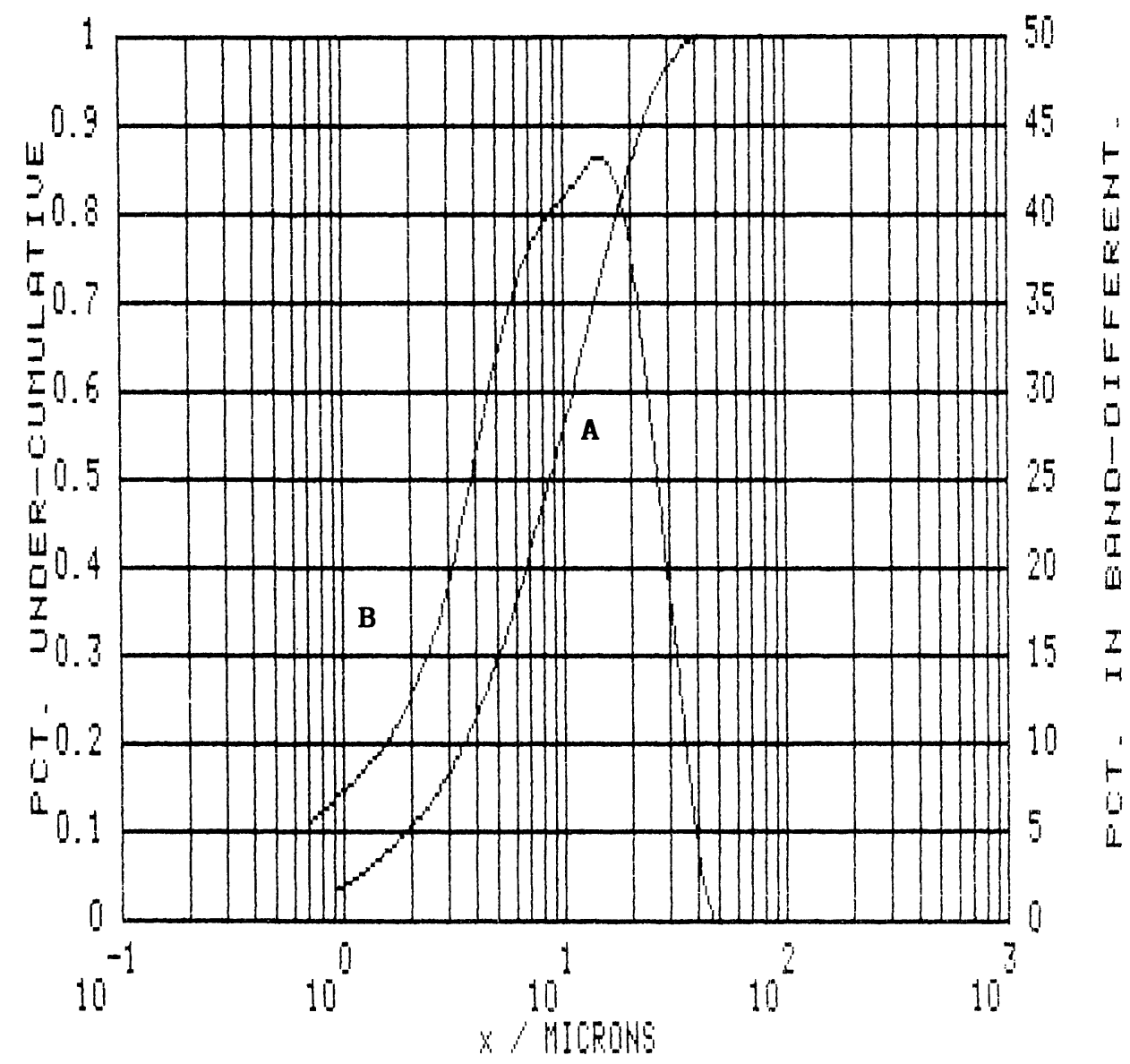

Fig. 3.-Análisis granulométrico. Arenisca (residuo inferior a $20 \mu \mathrm{m}$ ).

A: Curva de distribución del tamaño de partícula.

B: Curva de densidad de distribución.

Fig. 3.-Granulometric analysis. Sandstone (residue under $20 \mu \mathrm{m}$ ).

A: Distribution curve of particle size.

B: Curve of distribution density. 


\section{Método}

Para la medida de la movilidad de las partículas suspendidas, mediante la técnica de electroforesis se ha utilizado un Analizador de Potencial Zeta, Micromeritics-Modelo 1202 (Fig. 4). Consta de una célula donde se introduce la suspensión a estudiar y que, para evitar la sedimentación de las partículas durante la realización del ensayo, se mantiene en movimiento (25-35 r.p.m.). Posee dos electrodos situados uno frente al otro en la cámara de transporte de muestra. El electrodo de la célula es reversible electrolíticamente; según la polaridad de este electrodo, al aplicar una diferencia de potencial entre los electrodos las partículas emigran y, dependiendo de como sea su carga positiva o negativa, se mueven del exterior al interior de la célula o viceversa. Con ello se produce una variación en la concentración de las partículas en la célula, aumentando o disminuyendo, en relación con el sentido de la migración de la muestra. Estas variaciones se analizan gravimétricamente y a partir de estos datos se obtienen la movilidad electroforética y el potencial zeta.

\section{Method}

A Micromeritics Model 1202 (Fig. 4) Zeta Potential Analyzer was used to measure suspended particle mobility using the electrophoresis technique.

This device consists of a cell where the solution to be tested is introduced and kept in motion (25-35 r.p.m.) to prevent particle deposit while the test is under way. Two electrodes are placed opposite each other inside the sample holder chamber. The cell electrode is electrolithically reversible; depending on the polarity of this electrode, when a potential difference is applied across the two electrodes, particles migrate and move from the outside to the inside of the cell or vice-versa, according to the kind of charge, negative or positive. This causes variations in particle concentration. Particle concentration increases or decreases depending on the orientation of the migration in the sample. Such variations are gravity measured and from these data the electrophoretic mobility and zeta potential are obtained.

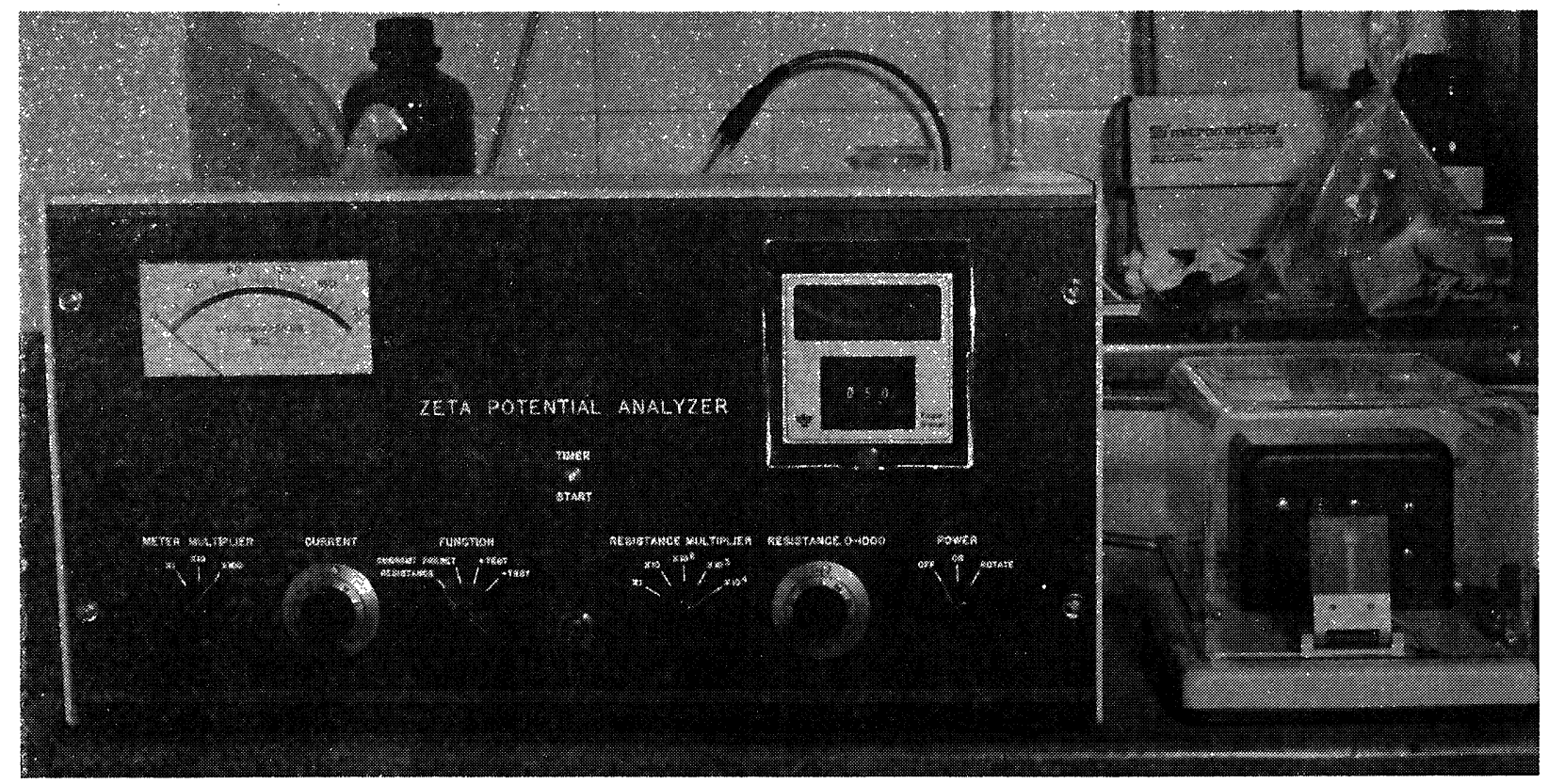

Fig. 4.-Analizador del potencial zeta.

Fig. 4.-Zeta potential analyzer.

\section{Resultados y Discusión}

Las condiciones de ensayo para la determinación del potencial zeta se han mantenido constantes durante la realización de todas las medidas. La temperatura de ensayo fue de $25 \pm 2^{\prime \prime} \mathrm{C}$.

\section{Results and Discussion}

Test conditions to determine the zeta potential were kept constant throughout the entire measuring process. The test temperature was $25 \pm 2^{\circ} \mathrm{C}$ and a $6 \mathrm{~g}$ of sample in $100 \mathrm{ml}$ of water was established. 
Los resultados obtenidos, dejando una concentración de $6 \mathrm{~g}$ de muestra en $100 \mathrm{ml}$ de agua destilada, muestran que a mayor finura de la muestra, entre 3.500 y $6.000 \mathrm{~cm}^{2} / \mathrm{g} \mathrm{u}$.B., el valor absoluto de la medida del potencial zeta se incrementa: desde $-13 \mathrm{mV} a-25 \mathrm{mV}$. Malek, Silsbee y Roy (1986) (12) encontraron esta misma tendencia al estudiar diferentes escorias.

Al realizar la medida del potencial zeta a concentraciones más bajas $(0,5,1$ y $2 \%$ de muestra) se observó que no existe una relación lineal entre la concentración y el potencial medido, por lo que la realización de esta medida para la comparación de resultados exigirá unas condiciones prefijadas extrictamente.

La medida del potencial zeta es posible en los sistemas material silíceo-agua $\mathrm{y} / \mathrm{o}$ disoluciones. En su aplicación a la arenisca, con una puesta a punto previa que fije para este material las condiciones de ensayo, se obtienen valores reproducibles, lo que permitirá utilizar estas determinaciones para estudios posteriores en la preparación de morteros fabricados a base de arenisca y otros productos de reparación con objeto de seleccionar el más adecuado para un empleo concreto, asi como para el estudio estructural mediante técnicas instrumentales (DRX, MEB,...) de cada una de las fracciones granulométricas y su relación con el comportamiento en la medida del potencial zeta.

En las investigaciones sobre la determinación del potencial zeta en el cemento, se aconseja utilizar muestras con partículas cuyos tamaños sean inferiores a $50 \mu \mathrm{m}$, con objeto de que la sedimentación no sea tan rápida y los valores que se obtengan puedan ser fiables.

En la práctica, el material se habrá de emplear con unas características físicas concretas en cuanto a su finura y no parece posible, en principio, realizar una separación de partículas con arreglo a su tamaño, con objeto de seleccionar una fracción óptima. No obstante, se realizaron ensayos de la medida del potencial zeta correspondientes a la fracción inferior a $20 \mu \mathrm{m}$ extraída de la muestra molida a $6.000 \mathrm{~cm}^{2} / \mathrm{g} \mathrm{u}$. B., observándose que alcanza valores aún más negativos que aquellos que corresponden al potencial zeta de la muestra en su conjunto.

Sin embargo, estos resultados no son estrictamente comparables, debido a que se trata de dos muestras de composición mineralógica diferente, ya que la fracción correspondiente al residuo inferior a $20 \mu \mathrm{m}$ ha
The results obtained show that increase of the fineness of the sample between 3,500 and $6,000 \mathrm{~cm}^{2} / \mathrm{g} \mathrm{u}$. B., the absolute value of the zeta potential reading increases from - $13 \mathrm{mV}$ to $-25 \mathrm{mV}$. Malek, Silsbee and Roy (1986) (12) found this same tendency when studying different slags.

When the zeta potential was measured at lower sample concentrations (0.5, 1 and $2 \%)$, it was observed that no linear relationship existed between concentration and the measured potential and thus, performing this measurement with the goal of comparing results will require rigidly preset conditions.

The zeta potential in the Systems siliceous material-water and/or solutions can be measured. In its application to sandstone, with previously specific test conditions set up for this material, reproducible values can be obtained. This will permit using these determinations in future studies for the preparation of sandstone-based mortars and other repair products, with the purpose of selecting the most suitable one and carrying out, using instrumental techniques (DRX, SEM, etc.), structural studies of each particle size fraction and its behavioural relationship with the measuring of the zeta potential.

Using samples with particle size under $50 \mu \mathrm{m}$ is recommended in research works on zeta potential determination. This will help reducing the deposit rate and making obtained values more reliable.

In actual practice, the material to be used should have certain specific physical properties regarding fineness and in principle, it does not seem possible to separate the particles by size to the end of selecting an optimum fraction. The test was conducted nevertheless measuring the zed potential of the fraction under $20 \mu \mathrm{m}$ extracted from the sample milled to $6,000 \mathrm{~cm}^{2} / \mathrm{g} \mathrm{u}$. B. It was then observed that even more negative values were reached than in the zeta potential measured in the entire sample.

But these results are not totally comparable as the two samples had different mineralogical compositions. The fraction belonging to the residue under $20 \mu \mathrm{m}$ was enriched in its clay content relative to the total sample and its 
quedado enriquecida en su proporción de arcilla respecto a la muestra total y cuyo comportamiento en la movilidad electroforética ha de ser diferente. En este aspecto queda abierta una línea de investigación futura.

En la figura 5 se representan los difractogramas de rayos $X$ correspondientes a la muestra de arenisca $6.000 \mathrm{~cm}^{2} / \mathrm{g} \mathrm{u}$.B. (I) y el residuo superior a $20 \mu \mathrm{m}$ de dicha arenisca (II).

Se observa como en el residuo superior a $20 \mu \mathrm{m}$, la fracción ha quedado enriquecida en cuarzo y feldespatos, mientras que disminuye en ella la montmorillonita. electrophoretic mobility had to be different. In this area a new line of research is open.

Figure 5 represents the $X$-ray difractograms of the $6,000 \mathrm{~cm}^{2} / \mathrm{g} \mathrm{u}$. B. (I) sandstone sample and of the residue upper than $20 \mu \mathrm{m}$ of the same sandstone (II).

It can be observed the fraction in the residue upper than $20 \mu \mathrm{m}$ was enriched in its contents of quartz and feldspats, while the contents of montmorillonite was reduced.

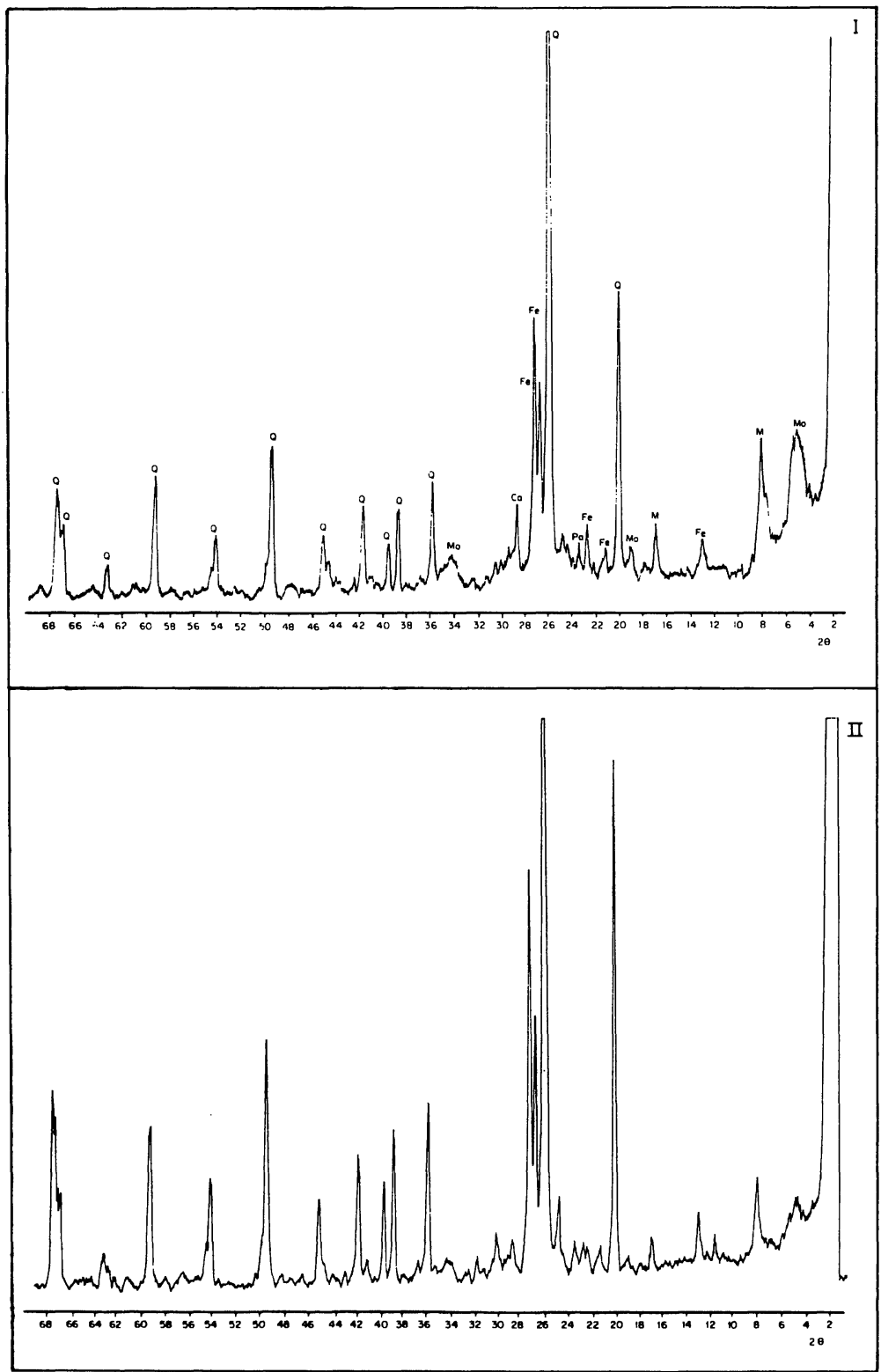

Fig. 5.-Difractogramas de arenisca.

I. Arenisca $6.000 \mathrm{~cm}^{2} / \mathrm{g} \mathrm{u}$. Blaine.

II. Residuo superior a $20 \mu \mathrm{m}$.
Fig. 5.-Sandstone difractograms.

I. $6,000 \mathrm{~cm}^{2} / \mathrm{g}$ u. Blaine Sandstone.

II. Residue upper than $20 \mu \mathrm{m}$. 


\section{AGRADECIMIENTO}

Los autores agradecen a la Comisión Interministerial de Ciencia y Tecnología (CICYT) el aporte económico para la realización de este trabajo.

\section{ACKNOWLEDGEMENT}

The authors wish to express their gratitude to the Inter-Ministerial Commission on Science and Technology (CICYT) for its financial support that made possible the present work.

\section{BIBLIOGRAFIA}

(1) F. MASSAZZA, H. TESTOLIN: II cemento, 2, 73-146 (1980).

(2) U. COSTA, F. MASSAZZA: II cemento, 3, 127-140 (1984).

(3) D. M. ROY, M. DAIMON, K. ASAGA: 7 th Inter. Congr. Chem. Cem., Paris. Vol. II, 242-246 (1980).

(4) M. DAIMON, D. M. ROY: Cem. Concr. Res., 9, 103-110 (1979).

(5) E. NÄGELE: Cem. Concr. Res., 15, 453-462 (1985).

(6) U. COSTA, F. MASSAZZA: 8th Int. Congr. Chem. Cem., Brasil. Vol. VI, 248-259 (1986).

(7) P. J. ANDERSEN, A. KUMAR, D. M. ROY, D. WOLFE: Confer. Cem. Concr. Res., Vol. 16, 255-259 (1986).

(8) F. MASSAZZA, U. COSTA, A. BARRILA: Journal of the American ceramic Society. Vol. 65, n. 4, 203-207 (1982).

(9) R. I. A. MALEK, D. M. ROY: Mat. Res. Soc. Symp. Proc. Vol. 43, 41-50 (1985).

(10) N. TENOUTASSE, A. M. MARION: Second Int. Conf. "Fly Ash, Silica Fume, Slag and Natural Pozzolans in concrete", Vol. 1, 51-76 (1986).

(11) T. MANGIALARDI, A. E. PAOLINI: II cemento, 4, 337-350 (1987).

(12) R. I. A. MALEK, M. SILSBEE, D. M. ROY: 8th Int. Cong. Chem. Cem., Brasil. Vol. IV, $270-275$ (1986).

(13) M. T. MARTÍN PATINO, J. SAAVEDRA, M. I. SÁNCHEZ de ROJAS, M. P. de LUXÁN, F. MADRUGA: European Symp. "Science, Technology and European Cultural Heritage", Bologna (Italia) (1989).

\section{publicaciones del IETcc/CSIC}

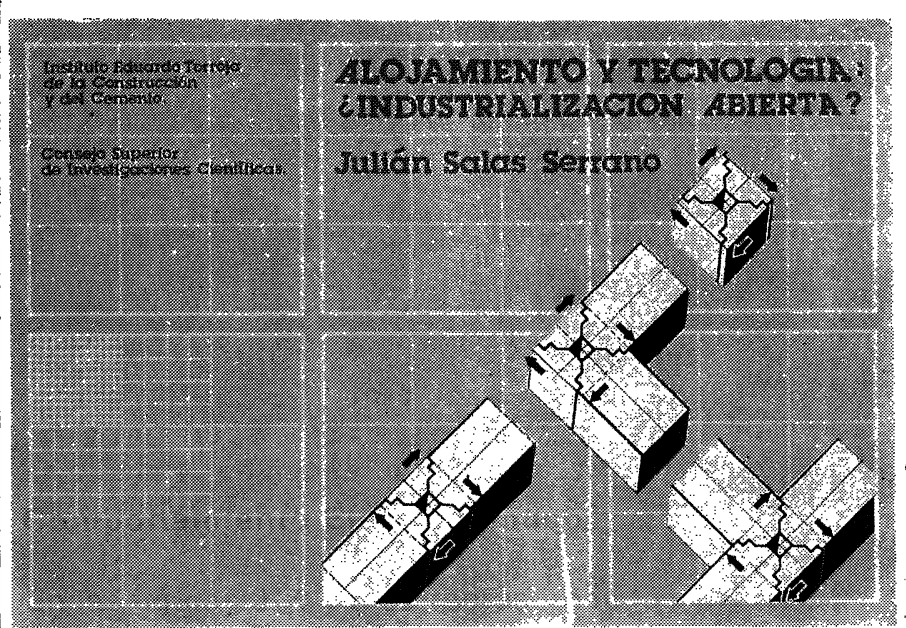

\section{ALOJAMIENTO Y TECNOLOGIA: ¿INDUSTRIALIZACION ABIERTA?}

JULIAN SALAS, ING. IND. (I.E.T.c.c.)

Un volumen de 160 páginas, 109 figuras y 16 tablas. Tamaño $240 \times 168 \mathrm{~mm}$. Encuadernado en rústica. Precios: España, 1.200 ptas; extranjero, 17 \$ USA.

\section{SUMARIO:}

Prólogo Prof. G. Ciribini.

\section{Introducción}

Capitulo 1.- La industrialización en las proclamas y manifiestos de arquitectura.

Capítulo 2.- ¿Réquiem por la construcción industrializada?

Capitulo 3.-Algunos conceptos básicos.

Capitulo 4.- ¿Proyecto tradicional, construcción industrializada?

Capitulo 5.-Componentes.

Capítulo 6. - La coordinación dimensional hoy.

Capítulo 7.-Flexibilidad, intercambiabilidad y catálogos.

Capítulo 8. - Industrialización, normativa y calidad.

Capitulo 9.-Reflexiones finales.

publicación del

INSTITUTO EDUARDO TORROJA 